\title{
Mengintegrasikan Pendidikan Karakter dalam Pembelajaran di SD Swasta Pangeran Antasari Helvetia 2022
} \author{
Siti Rahmadhani Siregar ${ }_{1,2,3,4,5}$ Sugito $^{2}$, Amir Danis ${ }^{3}$, Saut Mardame Simamora ${ }^{4}$, Sri ramadhani ${ }^{5}$ \\ Pendidikan Guru Sekolah Dasar (PGSD), STKIP Pangeran Antasari \\ E-mail: sugitotami@gmail.com ; danisamir829@gmail.com ; saut.m.simamora@gmail.com; \\ sramadhani1988@gmail.com
}

\begin{abstract}
Abstrak
Karakter merupakan titian ilmu pengetahuan dan keterampilan. Pengetahuan dan keterampilan tanpa adanya landasan kepribadian yang benar akan menyesatkan dan menghancurkan. Karakter yang berupa kepribadian tersebut dimuliki melalui proses pendidikan. Peran guru membantu dalam pembentukan watak siswa dengan cara memberikan keteladanan, cara berbicara atau menyampaikan materi yang baik, toleransi, dan berbagai hal yang terkait. Peneliti menggunakan metode pendekatan dengan kegiatan pelatihan dalam pengabdian kepada masyarakat ini. Kesimpulan menyatakan bahwa pelatihan ini cukup berhasil dimana peserta pelatihan sangat antusias dalam kegiatan pelatihan, hal tersebut juga karena masing-masing guru belum pernah mendapatkan sosialisasi dari pemerintah terkait kebijakan pemerintan dengan memberikan Penguatan Pendidikan Karakter di Sekolah.
\end{abstract}

Kata Kunci : Pendidikan Karakter, Pelatihan, Pengabdian Kepada Masyarakat

\begin{abstract}
Character is a foothold of knowledge and skills. Knowledge and skills without the right personality foundation will be misleading and destructive. The character in the form of personality is owned through the educational process. The role of the teacher helps in shaping the character of students by providing examples, ways of speaking or delivering good material, tolerance, and various other related matters. The researcher uses an approach method with training activities in this community service. The conclusion stated that this training was quite successful where the trainees were very enthusiastic in training activities, this was also because each teacher had never received socialization from the government regarding government policies by providing Strengthening Character Education in Schools.
\end{abstract}

Keywords: Character Education, Training, Community Service

\section{PENDAHULUAN}

Karakter merupakan titian ilmu pengetahuan dan keterampilan. Pengetahuan dan keterampilan tanpa adanya landasan kepribadian yang benar akan menyesatkan dan menghancurkan. Karakter yang berupa kepribadian tersebut dimuliki melalui proses pendidikan.(Ma'mur J, 2012) Pendidikan karakter adalah segala usaha yang dapat dilakukan untuk mempengaruhi karakter siswa(Ramdhani, 2017). Dengan kata lain pendidikan karakter merupakan suatu usahayang disengaja untuk membantu 
seseorang sehingga seseorang tersebut dapat memahami, memperhatikan (Margariena et al., 2017a), dan melakukan nilai-nilai etika. (Arikunto, 2012)Peran guru membantu dalam pembentukan watak siswa dengan cara memberikan keteladanan,(Hasibuan, 2017) cara berbicara atau menyampaikan materi yang baik, toleransi, dan berbagai hal yang terkait lainya.

Menurut (Suyanto, 2011), pendidikan karakter adalah pendidikan budi pekerti plus, yaitu yang melibatkan aspek pengetahuan (cognitive), perasaan (feeling) (Daar \& Ndorang, 2020), dan tindakan (action). Sehingga sangatlah penting pendidikan karakter diterapkan dalam pendidikan formal. Hal tersebut sesuai dengan Undang-Undang Sisdiknas Nomor 20 tahun 2003 pasal 3 yaitu Pendidikan Nasional berfungsi mengembangkan kemampuan dan membentuk watak serta peradapan bangsa yang bermartabatdalam rangka mencerdaskan kehidupan bangsa,(Salsabilah et al., 2021) bertujuan untuk berkembangnya potensi peserta didik agar menjadi manusia yang beriman dan bertaqwa kepada Tuhan Yang Maha Esa, berakhlak mulia, sehat, berilmu, cakap, kreatif,mandiri, dan menjadi warga negara yang demokratis serta bertanggung jawab. Pendidikan karakter juga didukung peraturan presiden Nomor 87 Tahun 2017 tentang penguatan pendidikan karakter.(Agustin, 2021)

Penguatan pendidikan karakter (PPK) (Anshori, 2017)merupakan program pendidikan di sekolah untuk memperkuat karakter siswa melalui harmonisasi olah hati (etika), olah pikir (literasi), (Arifin, 2017)dan olah raga (kinestetik) dengan dukungan pelibatan publik dan kerja sama antara sekolah, keluarga, dan masyarakat yang merupakan dari Gerakan Nasional Revolusi Mental (GNRM).(Apriawan \& Ekowati, 2021

Berdasarkan hasil observasi dan wawancara dengan beberapa guru SMP pada bulan Januari 2022, dapat disimpulkan bahwa peguatan pendidikan karakter sangatlah penting untuk siswa, tetapi masih banyak kendala yang dihadapi dalam penerapannya. Salah satunya adalah kurangnya pemahaman guru tentang penguatan pendidikan karakter di sekolah. Hal tersebut mengakibatkan rendahnya usaha guru untuk memperkuat karakter siswa yang akan berakibat pula pada rendahnya potensi yang dimiliki oleh siswa. Selain itu kurangnya saranadan prasarana yang mendukung penguatan pendidikan karakter di sekolah.

\section{Rumusan Masalah}

1. Apakah guru dapat mengintegrasikan pendidikan karakter sebelum dilakukan pelatihan mengintegrasikan pendidikan karakter dalam pembelajaran?

2. Bagaimana tingkat pemahaman guru mengintegrasikan pendidikan karakter dalam pembelajaran sesudah dilakukan pelatihan mengintegrasikan pendidikan karakter dalam pembelajaran?

\section{Tujuan}

Berdasarkan latar belakang dan rumusan masalah yang sudah dipaparkansebelumnya, maka tujuan utama dari kegiatan ini adalah:

1. Memberikan pengetahuan terhadap guru untuk mengintegrasikan pendidikankarakter dalam pembelajaran.

2. Menguji kemampuan guru untuk mengintegrasikan pendidikan karakter dalampembelajaran saat proses belajar mengajar.

\section{Manfaat}

Dengan dilaksanakannnya kegiatan PKM ini, ada beberapa manfaat yangdiharapkan bisa diperoleh dari akhir kegiatan ini, yaitu; 


\section{Untuk masyarakat sasaran, yaitu;}

1. Guru mendapatkan pengetahuan tentang mengintegrasikan pendidikan karakterdalam pembelajaran saat proses belajar mengajar.

2. Guru mengetahui tingkat kemahiran untuk mengintegrasikan pendidikan karakter dalam pembelajaran saat proses belajar mengajar.

\section{Untuk dosen yang melakukan PKM}

1. Bertambahnya pengalaman dalam kegiatan akademis serta bentuk tanggungjawab sebagai pendidik untuk memberikan informasi kepada masyarakat.

2. Memenuhi tri dharma dosen sebagai tenaga professional dalam bidang profesimasngmasing.

\section{METODE PENELITIAN}

\section{STRATEGI PELAKSANAAN PELATIHAN}

\section{Berdasarkan kesepa}

katan dengan sekolah mitra untuk menyelesaikan permasalahyang ada maka pengusul proposal menggunakan metode pendekatan dengan kegiatan pelatihan dalam pengabdian kepada masyarakat ini. Pelatihan akan dilaksanakan dengan duatahap yaitu teori dan praktek atau penerapannya yang berupa contoh-contoh kegiatan yang dapat memperkuat pendidikan karakter di sekolah dasar (Heru \& Yuliani, 2020). Kerjasama sekolah mitra dan peran aktifnya dalam kegiatan pelatihan sangat diharapkan demi keberhasilan pelatihan ini. Dalam pelatihan ini akan didukung oleh beberapa narasumber yang akan menyampaikan materinya. Pada kegiatan pertama peserta pelatihan akan menerima materi pentingnya pendidikan karakter dan arah kebijakan pemerintah tentang penguatan pendidikan karakter di sekolah. Kemudian pada tahap kedua peserta akan mendapatkan materi peran guru dalam pendidikan karakter serta praktek pelaksanaan pendidikan karakter di sekolah oleh guru SD Swasta Pangeran Antasari

\section{PERSIAPAN MELAKUKAN PELATIHAN}

Untuk melakukan kegiatan pengabdian kepada masyarakat ini diperlukan beberapa langkah-langkah persiapan yang meliputi;

1. Persiapan komponen dan perlengkapan. Dalam melakukan pelatihan ini dibutuhkan beberapa peralatan seperti;

- $\quad$ Laptop

- $\quad$ Materi (hand out)

- $\quad$ Proyektor

- $\quad$ Sound System

2. Proses penjelasan (tutorial) oleh dosen yang melakukan pengabdian masyarakat 3 hari 
(6 X 60 menit)

3. Mengadakan diskusi singkat, tanya jawab dan problemsolving kepada para siswa sebagai peserta.

\section{HASIL DAN PEMBAHASAN}

\subsection{PELAKSANAAN KEGIATAN}

\section{REALISASI PELAKSANAAN KEGIATAN}

Berdasarkan permasalahan yang dihadapi sekolah mitra, maka solusi yang ditawarkan adalah pemberdayaan guru SD dalam penguatan pendidikan karakter di kecamatan Percut Sei Tuan. Adapun rencana kegiatan yang akan dilaksanakan pada:

Tanggal/Bulan/Tahun

Tempat

Jumlah Peserta
: 5 Januari 2022

: SD Swasta Pangeran Antasari Helvetia

$: 25$

\section{Konsep dan Teknik Acara Pelatihan}

\begin{tabular}{|c|c|c|}
\hline No. & Waktu & Acara \\
\hline 1. & $08.00-08.30$ & $\begin{array}{l}\text { a. } \text { registrasi peserta } \\
\text { b. pembagian materi dan seminar kit } \\
\text { c. mengkoordinasikan peserta pelatihan untuk siap } \\
\text { mengikuti pelatihan. }\end{array}$ \\
\hline 2. & $08.30-08.45$ & $\begin{array}{l}\text { Pembukaan } \\
\text { a. Membuka pelatihan dengan bacaan hamdalah oleh } \\
\text { pembawa acara. } \\
\text { b. Menyanyikan lagu Indonesia Raya }\end{array}$ \\
\hline 3. & $08.45-09.00$ & $\begin{array}{l}\text { Sambutan } \\
\text { a. Ketua STKIP Pangeran Antasari } \\
\text { b. Ketua pelaksana Pelatihan " Peningkatan Kemampuan } \\
\text { Guru Mengintegrasikan Pendidikan Karakter dalam } \\
\text { Pembelajaran di SD Swasta Pangeran Antasari" }\end{array}$ \\
\hline 4. & $09.00-12.00$ & $\begin{array}{l}\text { Pelatihan } \\
\text { a. Pemaparan pentingnya pendidikan karakter untuk siswa. } \\
\text { b. Peran guru dalam penguatan pendidikan karakter }\end{array}$ \\
\hline 5. & $12.00-13.00$ & ISHOMA \\
\hline 6. & $13.0-14.00$ & $\begin{array}{l}\text { a. Pemaparan materi tentang arah kebijakan pemerintah } \\
\text { terkait penguatan pendidikan karakter. }\end{array}$ \\
\hline 7. & $14.00-15.30$ & $\begin{array}{l}\text { a. Pemaparan tentang tips efektif penguatan pendidikan } \\
\text { karakter di sekolah. }\end{array}$ \\
\hline 8 . & $15.30-16.00$ & $\begin{array}{l}\text { Penutup } \\
\text { a. Doa } \\
\text { b. Pembagian sertifikat }\end{array}$ \\
\hline
\end{tabular}




\section{PORTAL RISET DAN INOVASI PENGABDIAN MASYARAKAT (PRIMA) \\ VOLUME 1 ISSUE 2 (2022)}

\subsection{Hasil Kegiatan}

Kegiatan awal yang dilakukan setelah mendapat izin dari Kepala Sekolah adalah berkordinasi dengan salah seorang guru SD Swasta Pangeran Antasari Helvetia tersebut untuk mobilisasi pesertadan kordinasi dengan para guru yang lain demi kelancaran kegiatan ini. SD Swasta Pangeran Antasari ini dipilih karena sekolah ini merupakan salah satu sekolah di pusat kota yang sangat strategis. Para guru merupakan peserta yang memiliki kompetensi tinggi dan visi misi sekolahyang mengutamakan pembelajaran yang dinamis dan inovatif sehingga kegiatan ini merupakan aktivitas yang sangat mendukung program di sekolah ini. Kegiatan yang dilakukan pada hari Selasa, 5 Januari 2022 pada pukul 08.00 WIB sampai dengan 16.00 WIB berjalan dengan lancar.

Adapun temuan atau hasil kegiatan ini adalah;

1. Semua peserta antusias dalam acara ini karena dari semua peserta yang hadir, kegiatan ini adalah kegiatan pertama yang pernah merekaikuti.

2. Total peserta adalah 25 Guru dari SD Swasta Pangeran Antasari

3. Peserta mengalami kesulitan dalam mengintegrasikan pendidikan karakter di dalampembelajaran dan siswa kurang paham apa itu pendidikan karakter.

4. Permasalahan kurangnya pemahaman tentang penguatan pendidikan karakter di sekolah mitra menyebabkan perlunya sosialisasi tentang penguatan pendidikan karakter. Kegiatan sosialisasi ini juga mendukung kebijakan pemerintah yang tertuang dalam peraturan presiden Nomor 87 tahun 2017. Dalam hal ini sosialisasi di lakukan dengan pemaparan materi dan diskusi tentang:
a. Pemaparan pentingnya pendidikan karakter untuk siswa.
b. Peran guru dalam penguatan pendidikan karakter
c. Metodologi dalam pendidikan karakter.
d. Tips efektif penguatan pendidikan karakter di sekolah.

\section{KESIMPULAN}

Berdasarkan hasil Pengabdian Kepada Masyarakat dengan judul Peningkatan Kemampuan Guru Mengintegrasikan Pendidikan Karakter dalam Pembelajaran di SD Swasta Pangeran Antasari 2022 dapat ditarik kesimpulan bahwa pelatihan ini cukup berhasil dimana peserta pelatihan sangat antusias dalam kegiatan pelatihan, hal tersebut juga karena masing-masing guru belum pernah mendapatkan sosialisasi dari pemerintah terkait kebijakan pemerintan dengan memberikan Penguatan PendidikanKarakter di Sekolah. Dari hasil pendampingan menunjukkan masingmasingguru telah mengembangkan pemahaman dan pengetahuannya terkait Pendidikan karakter di sekolah. Hal tersut tampak dari hasil angket guru yang telah menerapkan pendidikan karakter di berbagai kegiatan di sekolah. Saran yang dapat diberikan yaitu sebelum meminta siswa untuk memiliki karakter, sebaiknya guru telah memiliki karakter yang baik. Karena guru adalah suri tauladan dan panutan bagi siswa di sekolah. Serta sekolah juga harus dapat memfasilitasi dan meberikan kebijakan terkait pendidikan karakter anak di sekolah. 


\section{DAFTAR PUSTAKA}

Agustin, N. (2021). Peran Guru dalam Membentuk Karakter Siswa. Peran Guru Dalam Membentuk Karakter Siswa (Antologi Esai Mahasiswa Pendidikan Guru Sekolah Dasar), 1 .

Anshori, I. (2017). Penguatan Pendidikan Karakter di Madrasah. Halaqa: Islamic Education Journal, 1(2), 63-74.

Apriawan, R., \& Ekowati, S. (2021). PENGUATAN KARAKTER ANAK-ANAK MELALUI GERAKAN NASIONAL REVOLUSI MENTAL (GNRM) DI DESA KETAPANG BARU SELUMA BENGKULU. JIMAKUKERTA, 1(1), 85-89.

Arifin, S. (2017). Peran Guru Pendidikan Jasmani Dalam Pembentukan Pendidikan Karakter Peserta Didik. Multilateral: Jurnal Pendidikan Jasmani Dan Olahraga, 16(1).

Arikunto, S. (2012). Dasar-dasar evaluasi pendidikan edisi 2. Jakarta: Bumi Aksara.

Daar, G. F., \& Ndorang, T. A. (2020). Pembudayaan Perilaku Bersih dan Peduli Lingkungan di Dusun Nanu untuk Mendukung Gerakan Nasional Revolusi Mental 2019. JPKMI (Jurnal Pengabdian Kepada Masyarakat Indonesia), 1(2), 116-124.

Hasibuan, R. P. (2017). Peran guru dalam pendidikan.

Ma'mur J, A. (2012). Pendidikan Karakter di Sekolah. Jogjakarta : DIVA Press.

Margariena, I. N., Imron, A., \& Burhanuddin, B. (2017a). Mengintegrasikan Pendidikan Karakter Dalam Pembelajaran di Sekolah Dasar. Prosiding Seminar Nasional Mahasiswa Kerjasama Direktorat Jenderal Guru Dan Tenaga Kependidikan Kemendikbud 2016.

Ramdhani, M. A. (2017). Lingkungan pendidikan dalam implementasi pendidikan karakter. Jurnal Pendidikan UNIGA, 8(1), 28-37.

Salsabilah, A. S., Dewi, D. A., \& Furnamasari, Y. F. (2021). Peran Guru Dalam Mewujudkan Pendidikan Karakter. Jurnal Pendidikan Tambusai, 5(3), 7158-7163.

Suyanto, S. (2011). Implementasi Pendidikan Karakter melalui Pembelajaran Terpadu. Yogyakarta: Universitas Negeri Yogyakarta. 